\title{
MEMBANGUN GENERASI “GREAT” BERETIKA MENUJU INDONESIA EMAS
}

\section{Dedi Wahyudi Novita Kurniasih}

Institut Agama Islam Negeri (IAIN) Metro

Jl. Ki Hajar Dewantara 15a Iringmulyo, Kota Metro, Lampung, Indonesia e-mail: podoluhur91@gmail.com dan novitakurniasih97@gmail.com

\begin{tabular}{|c|c|c|}
\hline Diterima: & Revisi: & Disetujui: \\
10 Mei 2019 & 18 Mei 2019 & 24 Mei 2019 \\
\hline
\end{tabular}

\begin{abstract}
Freedom of communication and opinion in cyberspace creates various problems, one of which is hoax. The severity of scattered hoax information tends to smell of SARA, slander, and provocative which often lead to someone dealing with the law. The openness and ease of accessing information makes it not a few people who directly share information without reading other sources or finding out the truth. Many people are not aware of the extraordinary impact of the hoax. Today, digital media is dominated by millennial youth, which are "digital natives". The realization of Indonesia gold 2045 is a form of integration-interconnection of various layers of society, culture, and various kinds of available resources. If this generation is not given strong ammunition to ward off hoax attacks, it is feared that the jargon of "Indonesia Emas 2045" is only a mere wish. Being a generation who is technologically savvy and understands its use is not enough, communication ethics are also needed. GREAT generation (Get, Read, Tabayyun) Ethics is the actualization of QS. al-Hujurat verse 6 which is expected to counteract the attacks and the effects of these hoaks. Explicitly, the Qur'an has given guidance to address the hoax that is integrated with the current era as an effort to realize Indonesia Golden 2045.
\end{abstract}

Keywords: Hoaxs, Indonesian gold, and digital natives.

\begin{abstract}
Abstrak
Kebebasan berkomunikasi dan berpendapat di dunia maya menimbulkan beragam masalah salah satunya hoaks. Parahnya informasi hoaks yang tersebar cenderung berbau SARA, fitnah, dan provokatif yang tak jarang menimbulkan seseorang berurusan dengan hukum. Keterbukaan dan mudahnya mengakses informasi membuat tidak sedikit masyarakat yang langsung men-share
\end{abstract}


informasi tanpa membaca sumber lain ataupun mencari tahu kebenarannya. Banyak orang yang tidak menyadari dampak luar biasa dari berita bohong tersebut. Saat ini, media digital didominasi pemuda millenial yang merupakan "digital natives". Terwujudnya Indonesia emas 2045 merupakan bentuk integrasi-interkoneksi berbagai lapisan masyarakat, budaya, serta berbagai macam sumber daya yang ada. Jika generasi ini tidak diberikan amunisi yang kuat untuk menangkal serangan hoaks, maka ditakutkan jargon "Indonesia Emas 2045" hanyalah angan belaka. Menjadi generasi yang melek teknologi dan faham pemanfaatanya tidaklah cukup, dibutuhkan pula etika berkomunikasi. Generasi GREAT (Get, Read, Tabayyun) Beretika merupakan aktualisasi dari QS. al-Hujurat ayat 6 yang diharapkan dapat menangkal serangan dan dampak dari hoaks tersebut. Secara eksplisit, al-Qur'an telah memberikan tuntunan untuk menyikapi hoaks yang diintegrasikan dengan zaman kekinian sebagai upaya mewujudkan Indonesia Emas 2045.

Kata kunci: Hoaks, Indonesia emas, dan digital natives

\section{A. Pendahuluan}

Gaungan “Indonesia Emas 2045” semakin kentara dengan berbagai macam ide, gagasan, dan wacananya. Hal ini tidaklah tanpa alasan, sebab ada suatu harta karun berharga yang dapat menja-dikannya modal untuk kemajuan Bangsa Indonesia. Harta karun yang dimaksudkan adalah bonus demografi. Tahun 2045 akan datang, Indonesia memiliki jumlah penduduk sekitar 70\%-nya berada di usia produktif (15-64 tahun) dan sisanya penduduk tidak produktif (usia kurang dari 14 tahun dan diatas 65 tahun). ${ }^{1}$

Salah satu ciri majunya peradaban adalah dengan semakin pesatnya perkembangan dunia teknologi dan semakin mudahnya mengakses informasi. Baik sekarang ataupun berapa tahun kedepan dunia IT tidak akan kehabisan "pamor" dikancah pergaulan dunia. Berkembang pesatnya teknologi, berbanding lurus dengan permintaan informasi. Teknologi yang berkembang diharapkan dapat mengobati rasa "haus" masyarakat akan informasi. Dari berkembangnya jumlah pemintaan masyarakat terhadap suatu informasi, beberapa pihak tertentu memanfaatkan pasar ini dengan menyajikan informasi yang tidak dapat dipertanggungjawabkan

${ }^{1}$ Rizkia Yulianti, “Generasi Emas Produktif, Indonesia Siap di Tahun 2045”, Good News From Indonesia, 2018. https://www.goodnewsfromindonesia.id/2017/11/21/indonesia-bisalahirkan-generasi-emas-bukan-micin. 
kebenarannya, bahkan informasi tersebut adalah buatan dengan unsur kesengajaan untuk berbohong.

Saat ini hoaks sudah menjamur bagai cendawan di musim hujan, terutama pada tahun-tahun politik. Kasus penyerangan ulama, hoaks penculikan anak, hoaks kesehatan, dan banyak lainnya. Pelaku penyebar hoaks dapat datang dari siapa saja dan dari mana saja. Pelaku yang mengatasnamakan tokoh, atau berlatar belakang pendidikan, pekerjaan tertentu, dan lainnya membuat masyarakat percaya begitu saja terhadap berita yang beredar.

BIN mengungkapkan bahwa terdapat $60 \%$ dari konten media sosial terindikasi hoaks. ${ }^{2}$ Jenis berita hoaks yang paling banyak beredar di situs online adalah masalah sosial politik. Menurut Shafiq Pontoh, Co-Founder Provetic menyebutkan, sekitar $91,8 \%$ berita hoaks adalah masalah sosial politik; 88,6\% masalah SARA; 41,2\% masalah kesehatan; 32,6\% masalah makanan dan minuman; $24,5 \%$ masalah penipuan keuangan; $23,7 \%$ masalah IPTEK; $18,8 \%$ masalah berita duka; $17,6 \%$ masalah candaan; $10,3 \%$ masalah bencana alam; dan $4 \%$ masalah lalu lintas. ${ }^{3}$

Dilihat dari data dan kasus di atas dapat dikatakan bahwa hoak telah parah dan merajalela di Indonesia saat ini. Berkaca dari kasus tersebut tentulah sangat memprihatinkan jika bangsa Indonesia hancur gara-gara hoaks. Sebagai generasi Muslim yang cerdas, tentulah menjadi kewajiban kita untuk bersama melawan hoaks agar tercip-tanya kondisi damai dan bersama mewujudkan Indonesia emas 2045.

Terdapat beberapa kajian mengenai hoaks, akan tetapi belum ditemukan kajian yang membahas mengenai urgensi generasi muda dalam menanggulangi hoaks untuk Indonesia emas 2045. Diantara kajian hoaks berkaitan dengan al-Qur'an dan hadis dibahas oleh Stepanus Sigit

\footnotetext{
${ }^{2}$ Kompas Cyber Media, "BIN: 60 Persen Konten Media Sosial adalah Informasi Hoaks", KOMPAS.com, 15 mars 2018. https://nasional.kompas.com/read/2018/03/15/06475551/bin60-persen-konten-media-sosial-adalah-informasi-hoaks.

${ }^{3}$ Nur Hidayah, "Langkah Cerdas Generasi Milenial di Era Digital Terhadap Informasi dan Berita Hoaks", KOMPASIANA, 6 novembre 2017. https://www.kompasiana.com/janurmisuwur/ 5a0008845a676f012e5ef892/langkah-cerdas-generasi-milenial-di-era-digital-terhadapinformasi-dan-berita-hoax.
} 
Pranoto $^{4}$, Luthfi Maulana5, Ratna Istriyani dan Nurhuda Widiyana6. Salah satu kajian dilakukan oleh Stepanus Sigit Pranoto yang berjudul "Inspirasi al-Qur'an dan Hadis dalam menyikapi Informasi Hoaks"7. Kajian tersebut membahas mengenai inspirasi al-Qur'an dan hadis terkait perilaku narsistik di media sosial sekaligus cara menyikapi informasi hoaks.

Berlatar dari berbagai realitas yang telah disebutkan di atas, maka kajian ini berusaha untuk mengupas upaya membentengi dari bahaya hoaks melalui generasi "GREAT Beretika" untuk mewujudkan Indonesia emas 2045 yang didasarkan pada pandangan QS. al-Hujurat ayat 6. Melalui kajian ini diharapkan dapat memberikan pemahaman kepada masyarakat mengenai bahya hoaks serta dapat mengarahkan umat Islam untuk lebih baik sehingga terciptalah integrasi-interkoneksi untuk mewujudkan bersama Indonesia emas 2045.

\section{B. Realitas Teknologi Informasi dan Komunikasi di Era Kini}

Hoaks tercipta karena masifnya penggunaan teknologi informasi dan komunikasi, oleh karenanya sebelum memaparkan tentang hoaks, kita perlu membahas realitas tekonologi informasi dan komunikasi di era kini. Mau tidak mau setiap individu harus terseret dalam arus perkembangan teknologi terlebih teknologi informasi dan komunikasi.

Pengembangan dan aplikasi dari alat, mesin, material dan proses yang dapat menolong manusia menyelesaikan pekerjaannya secara lebih efisien disebut dengan teknologi. ${ }^{8}$ Teknologi merupakan salah satu metode ilmiah guna mencapai tujuan praktis, ilmu pengetahuan terapan. Lebih

\footnotetext{
4 Stepanus Sigit Pranoto, "Inspirasi Alquran dan Hadis dalam Menyikapi Informasi Hoax", ALQUDS: Jurnal Studi Alquran dan Hadis 2, no 1 (22 juin 2018): 29-50, doi:10.29240/ alquds.v2i1.371.

${ }^{5}$ Luthfi Maulana, "Kitab Suci Dan Hoax: Pandangan Alquran Dalam Menyikapi Berita Bohong ", Wawasan: Jurnal Ilmiah Agama Dan Sosial Budaya 2, no 2 (30 décembre 2017): 209-22, doi:10.15575/jw.v2i2.1678.

${ }^{6}$ Ratna Istriyani et Nur Huda Widiana, "Etika Komunikasi Islam Vs Hoax Di Dunia Maya", Jurnal Ilmu Dakwah 36, no 2 (7 septembre 2017), doi:10.21580/jid.v36.2.1774.

7 Pranoto, "Inspirasi Alquran dan Hadis dalam Menyikapi Informasi Hoax"...

8 Teknologi sendiri berasal dari bahasa Yunani yaitu Technologia yang memilki arti penanganan terhadap sesuatu secara sistematis. Techne yang merupakan dasar dari kata teknologi berarti skill and science. Teknologi juga ada yang berependapat dari asal kata bahasa latin texere yang artinya adalah menyusun atau membangun yang tidak terbatas pada penggunaan mesin. Lihat dalam Tuti Andriani, "Sistem Pembelajaran Berbasis Teknologi Informasi Dan Komunikasi", Sosial Budaya 12, no 1 (4 août 2016): 132, doi:10.24014/sb.v12i1.1930.
} 
mudahnya bahwa teknolgi merupakan sarana yang diperlukan bagi kelangsungan hidup dan kenyamanan hidup manusia.

Informasi merupakan fakta atau apapun yang dapat digunakan sebagai input dalam menghasilkan informasi. Informasi didapat dari sejumlah data yang berkaitan. Jadi, informasi merupakan kumpulan data yang telah diolah melalui pengolahan data dalam rangka menguji tingkat kebenarannya dan ketercapaiannya sesuai dengan kebutuhan Kemudian, serangkaian proses bagaimana pengaliran ide dari satu sumber kepada satu penerima atau lebih guna membentuk dan melakukan pertukaran informasi satu dengan lainnya merupakan definisi dari komunikasi. ${ }^{9}$ Teknologi informasi dan komunikasi merupakan hasil dari rekayasa manusia terhadap proses penyampaian informasi dan proses penyampaian pesan antar pihak yang berkaitan agar lebih cepat, lebih luas, dan lebih lama dalam penyimpanannya.

Berkembangnya teknologi saat ini mengaburkan realitas batasan geografis dan sosial yang disebut dengan budaya elektronik. Realitas yang muncul saat ini adalah bentuk efek dari budaya elektronik itu sendiri. Seperti yang diungkapkan Paul Virillo bahwa teknologi dan perubahannya telah menarik masyarakat pada kehidupan yang dipenuhi dengan kecepatan dan begitu mempengaruhi. ${ }^{10}$ Realitas teknologi dapat kita temukan pada kehidupan masyarakat kekinian dimana teknologi dapat menentukan aktivitas masyarakat pada berbagai aspek seperti ekonomi, pendidikan, hukum, politik, sosial, dan budaya. Internet menjadi ruang publik yang tak kasat mata, dimana memungkinkan terjadinya pertukaran informasi, melakukan hubungan dan diskusi, jual beli, bahkan dunia politik.

Dari internet inilah kemudian berkembang komunitas maya yang dicirikan dengan berbagai relasi yang berkembang untuk saling bertukar informasi. Internet telah mengubah tatanan masyarakat dunia dalam berbagai bidang. Sebut saja dalam bidang ekonomi dimana sekarang trending dengan e-commerce. Ranah politik tidak menjadi tabu bagi pengguna internet. Mereka dapat berdiskusi ataupun menyalurkan

${ }^{9}$ Ibid., 133.

10 George Ritzer, Teori Sosial Posmodern, trad. Nurhadi (Yogyakarta: Kreasi Wacana, 2010), h. 231. 
aspirasi mereka mengenai keadaan politik bangsanya. Terdapat beberapa alasan mengapa manusia memilih bergabung dalam masyarakat virtual ini. ${ }^{11}$

Seiring dengan revolusi globalisasi serta teknologi, perkem-bangan media sosial berbasis internet juga semakin meningkat. Media sosial atau social media secara bahasa terdiri dari dua kata yaitu "social" yang berarti kemasyarakatan dan "media" yang berarti wadah atau tempat interaksi itu sendiri. ${ }^{12}$ Media sosial adalah berbagai macam aplikasi internet yang memungkinkan penggunanya menciptakan konten-konten dan interaksi antar sesama. ${ }^{13} \mathrm{Hal}$ ini tentunya memper-mudah interaksi sosial antar individu dimana tidak ada sekat antara ruang dan waktu. Media sosial memungkinkan setiap individu mengekspresikan dirinya ke ranah publik. Media sosial juga telah membawa perubahan pada integrasi sosial, reproduksi budaya, dan partisipasi politik. ${ }^{14}$ Saat ini terdapat bebagai macam media sosial, diantaranya adalah facebook, instagram, twitter, line, blog, BBM dan lainnya.

Jumlah pengguna internet pada tahun 2017 menurut data statistik yang dikeluarkan oleh APJII (Asosiasi Penyelenggara Jasa Internet Indonesia) mencapai 143,26 juta jiwa atau $54,68 \%$ dari jumlah total populasi penduduk Indonesia yang berjumlah 262 juta jiwa. ${ }^{15}$ Kemudian menurut Internet World Stats, sampai dengan 31 Desember 2017 jumlah pengguna internet Indonesia berada di urutan ke-5 dunia setelah China, India, USA, dan Brasil.16

${ }^{11}$ Pertama, kemudahan dalam bertukar informasi dan ide. Kedua, dukungan sosial. Ketiga, pertemanan. Keempat, sebgai saranan rekreasi dari penatnya aktivitas. Kelima, kesamaan minat. Terakhir adalah tentunya karena mudahnya dan murahnya akses. Lihat dalam Yuhdi Fahrimal, "Netiquette: Etika Jejaring Sosial Generasi Milenial Dalam Media Sosial", Jurnal Penelitian Pers Dan Komunikasi Pembangunan 22, no 1 (13 juin 2018): h. 66.

12 Eddy Saputra, "Dampak Sosial Media Terhadap Sikap Keberagaman Remaja dan Solusinya Melalui Pendidikan Agama Islam", Sosio e-kons 8, no 2 (29 octobre 2016): h. 164, http://journal.lppmunindra.ac.id/index.php/sosio_ekons/article/view/922.

${ }^{13}$ Pranoto, "Inspirasi Alquran dan Hadis dalam Menyikapi Informasi Hoax"..., h. 32.

14 Haryatmoko, Etika Komunikasi: Manipulasi Media, Kekerasan, dan Pornografi (Yogyakarta: Kanisius, 2007), h. 25.

15 Tim APJII, "Potret Zaman Now Pengguna dan perilaku Internet Indonesia", avril 2018, 1.

16 Internet World Stats, "Internet Top 20 Countries-Internet Users 2018", 2018. https://www.internetworldstats.com/top20.htm. 
Jika dilihat dari rentang usia pengguna internet, tingkat usia 19-34 tahun menempati jumlah terbesar (49,52\%), selanjutnya usia 35-54 tahun (29,55\%), usia 13-18 tahun (16,68\%), dan usia lebih dari 54 tahun sebanyak 4,24\%. ${ }^{17}$ Senada dengan hal tersebut, penelitian yang dilakukan Chambers terhadap generais milenial yang ada di Amerika Serikat mendapatkan fakta bahwa generasi ini mengakses media sosial 24 jam sehari sebagai wahana rekreasi. Dalam konteks Asia Tenggara terdapat penelitian di Malaysia bahwa kamu pelajar merupakan agen yang paling bergantung terhadap penggunaan internet. ${ }^{18}$ Di Indonesia, hasil riset menunjukkan, remaja menggunakan internet sebagai sarana rekreasi dan hal itu menyebabkan turunnya aktivitas belajar. ${ }^{19}$

Dari data ini dapat dilihat betapa usia produktif menjadi agen paling aktif dalam penggunaan internet. Sebagai pengguna paling aktif, generasi ini sangatlah sensitif terhadap isu-isu yang berkembang dan yang menjadi trending topic. Oleh karenanya sangatlah berpengaruh apabila generasi ini dibekali dengan pengetahuan bagaimana bijak dalam bermedia.

\section{Eksistensi Hoaks dalam Cyberspace}

Cyberspace (ruang maya) terbentuk dari realitas berkembangnya teknologi informasi dan komunikasi. Ruang maya merupakan suatu tempat dimana tidak diketahui jelas tempat itu berada. Disebut maya karena tidak menghadirkan fisik pengguna di ruangan tersebut. Tidak mengherankan apabila Poscoe dalam Fahrimal menyebut, bahwa era ini sebagai era polymedia. ${ }^{20}$ Era polymedia ditandai dengan ketergantungan penuh manusia kepada tiga teknologi komunikasi, yaitu: telepon, instant messenger, dan media sosial.

Cepatnya transmisi dan berbagai kemudahan dalam mengakses informasi tanpa identitas pasti memunculkan berbagai problem. Hoaks

\footnotetext{
17 Tim APJII, "Potret Zaman Now Pengguna dan perilaku Internet Indonesia"..., 1.

18 Normah Mustaffa et al., "Kebergantungan Internet Dan Aktiviti Online Remaja Di Lembah Kelang", Jurnal Komunikasi: Malaysian Journal of Communication 29, no 1 (2013): 200, http://ejournal.ukm.my/mjc/article/view/15033.

${ }_{19}$ Astutik Nur Qomariyah, "Perilaku Penggunaan Internet Pada Kalangan Remaja Di Perkotaan", Jurnal Palimpsest 1 (1 novembre 2009), http://journal.unair.ac.id/PALIM@perilakupenggunaan-internet-pada-kalangan-remaja-di-perkotaan-article-11111-media-86-category8.html.

${ }^{20}$ Fahrimal, "Netiquette: Etika Jejaring Sosial Generasi Milenial Dalam Media Sosial", h. 64.
} 
merupakan salah satu bayangan yang terus "mengekor" di belakang perkembangan teknologi komunikasi dan informasi. Hoaks dalam kata benda dapat diartikan dengan bermain tipu muslihat dengan orang lain untuk bercanda, serta apapun yang dengan sengaja digunakan untuk menipu atau memperdaya orang lain. Dalam bahasa Indonesia, hoaks merupakan kata serapan yang memiliki makna berita bohong atau berita palsu. ${ }^{21}$ Istilah hoaks dikenal pula dengan berita bohong, berita palsu, berita fitnah, dan istilah lainnya. ${ }^{22}$ Pada konteks media online, kata hoaks dapat dimaknai sebagai teks yang digunakan sebagai pemberitaan palsu atau upaya menipu yang di sebarkan melalui media siber kepada pembaca untuk mempercayai segala sesuatunya. ${ }^{23}$

Di dalam Islam, hoaks termasuk ke dalam perbuatan ghibah. Perbuatan ghibah adalah menceritakan seseorang yang tidak berada di tempat dengan sesuatu yang tidak disukainya (aib).24 Sebagaimana dikatakan dalam hadis;

"Dari Abu Hurairah, sesungguhnya Rasulullah saw bersabda: Tahukah kalian apa ghibah itu? Sahabat menjawab Allah dan Rasul-Nya yang lebih mengetahui. Beliau bersabda: "kamu menyebutkan saudaramu dengan sesuatu yang ia benci, "Beliau ditanya: Bagaimana kalau memang saudaraku melakukan apa yang kukatakan? Beliau menjawab: kalau memang sebenarnya begitu berarti engkau telah mengghibahnya, tetapi jika apa yang kau sebutkan tidak benar maka berarti engkau telah berdusta atasnya." HR Muslim.

Berdasarkan hadis di atas, ghibah merupakan perbuatan dimana ia menyatakan sesuatu yang terdapat pada diri seorang muslim disaat ia tidak berada di tempat. Kemudian apabila hal yang dibicarakan tersebut memang ada pada orang tersebut maka itu termasuk fitnah. ${ }^{25}$ Hoaks dapat dikaitkan dengan ghibah dalam Islam dikarenakan memiliki berbagai dampak yang dimunculkannya dapat merugikan berbagai macam pihak.

${ }^{21}$ Abd Mujib, "Pesan Al-Quran dalam Menyikapi Berita Hoax: Perspektif Dakwah di Era New Media", Jurnal Komunikasi Islam 7, no 1 (8 juin 2018): 50, doi:10.15642/jki.2017.7.1.42-65.

22 Pranoto, "Inspirasi Alquran dan Hadis dalam Menyikapi Informasi Hoax"..., h. 37.

${ }^{23}$ A. Yudo Triartanto, "Kredibilitas Teks Hoax Di Media Siber", Jurnal Komunikasi 6, no 2 (2015): h. 34, doi:10.31294/jkom.v6i2.2464.

${ }^{24}$ Hasan Sa'udi et Ahmad Hasan Irabi, Jerat-Jerat Lisan (Solo: Pustaka Arafah, 2014), 14.

${ }^{25}$ Lailatul Utiya Choiroh, "Pemberitaan Hoax Perspektif Hukum Pidana Islam", Al-Jinayah: Jurnal Hukum Pidana Islam 3, no 2 (2017): 340, doi:10.15642/aj.2017.3.2.325-348. 
Alasan orang menyebarkan berita hoaks adalah berita di dapatkan dari orang yang dianggapnya terpercaya, mengira berman-faat, mengira benar, dan ingin menjadi yang pertama tahu mengenai informasi yang disebarkannya. Sarana untuk penyebaran hoaks sangat bermacam. Saluran paling mudah adalah melalui media sosial seperti facebook, instragram, twitter, dan lainnya. selanjutnya aplikasi chatting juga dapat menumbuh-suburkan hoaks. Situs web yang menyediakan berbagai macam informasi dapat pula menjadi lahan penyebaran hoaks. Televisi, media cetak, email, dan radio sebagai media non internet juga dapat diinternalisasikan hoaks. ${ }^{26}$

Kemudahan dalam mengakses berita, berbagi, dan berkomentar melalui media sosial menumbuh suburkan hoaks. Informasi yang ada saling bertumpuk karena mudahnya dalam share dan copy. Hoaks biasanya dibuat oleh pihak-pihak tertentu yang dengan sengaja menyebarluaskannya untuk berbagai tujuan. Tujuan dari hoaks itu adalah untuk menggiring opini publik, membentuk persepsi baru, sekedar becanda, ataupun untuk menguji kecerdasan dan kecermatan pengguna internet dan media sosial. ${ }^{27}$ Seringnya berita hoaks memperbesar masalah-masalah yang menggelilingi suatu masalah inti, jadi fokusnya bukanlah kepada masalah inti. Masalah-masalah yang mengelilingi itu dibuat sedemikian rupa agar menarik minat masyarakat yang justru membuat masyarakat bingung tetapi seolah paham.

Tidak semua bentuk kebohongan dapat diidentifikasikan sebagai hoaks. Harley memberikan sejumlah karakteristik untuk mengidentifikasikan hoaks. Pertama, hoaks biasanya berupa pesan berantai. Di dalam pesan tersebut ada anjuran atau keharusan untuk menyebarkan informasi jika tidak maka akan terjadi sesuatu. Kedua, pada informasi hoaks tidak tercantum tanggal kejadian yang jelas. Suatu berita haruslah memuat unsur $5 \mathrm{~W}+1 \mathrm{H}$, akan tetapi pada berita hoaks tidak dapat dipastikan kejadian yang dibicarakan terjadi. Ketiga, informasi hoaks tidak

${ }^{26}$ Henri Septanto, "Pengaruh Hoax dan Ujaran Kebencian Sebuah Cyber Crime Dengan Teknologi Sederhana di Kehidupan Sosial Masyarakat", Kalbiscientia: Jurnal Sains dan Teknologi Vol. 5, no 2 (2 août 2018): h. 59.

27 Dedi Rianto Rahadi, "Perilaku Pengguna Dan Informasi Hoax Di Media Sosial." Jurnal Manajemen Dan Kewirausahaan", JURNAL MANAJEMEN DAN KEWIRAUSAHAAN 5, no 1 (30 juin 2017): 61, doi:10.26905/jmdk.v5i1.1342. 
memuat tanggal kedaluarsa. Maksudnya adalah informasi yang disajikan tidak dijelaskan kapan akan berakhir sehingga menim-bulkan keresahan bagi masyarakat. Keempat, tidak adanya organisasi atau penanggung jawab berita yang diturunkan. Tidak adanya sumber yang jelas menyebabkan kesimpang siuran sebuah berita sehingga tidak dapat dimintai pertanggung jawaban. ${ }^{28}$

Hoaks merupakan senjata paling ampuh untuk memusnahkan suatu bangsa, dimana rakyatnya akan berseteru dan tidak percaya satu sama lainnya sehingga terpecah belah. Informasi hoaks selalu menyentuh sisi emosional dan menyebabkan orang yang menerimanya tidak sadar bahwa dirinya sedang menerima suatu hoaks. Jauh sebelum abad milenium ini, di dalam sejarah Islam terdapat banyak catatan mengenai hoaks. Sebut saja hoaks pada kisah Nabi Isa AS. Maryam dituduh telah berbuat zina sehingga melahirkan seorang bayi tanpa adanya ayah. Allah sendirilah yang mengklarifikasi berita bohong tersebut dengan sebuah wahyu pada alQur'an Surat Maryam ayat 28. Kemudian pada masa Nabi Musa AS, Fir'aun menyebarkan sebuah berita bohong bahwa Nabi Musa AS adalah anak seorang penyihir yang akan merebut kekuasaan ayah angkatnya meskipun Fir'aun tahu bahwa apa yang ada pada diri Musa AS adalah mukjizat bukanlah penyihir. ${ }^{29}$

Selanjutnya, Nabi Muhammad SAW dan keluarganya tak luput dari serangan hoaks. Isteri Nabi, Aisyah ra juga pernah digosipkan berselingkuh dengan seorang laki-laki. Prahara yang ditimbulkan oleh hoaks tersebut menjadikannya asbabunnuzul dari ayat 11-15 QS. An-Nur.30 Khalifah Utsman bin Affan wafat karena ditikam oleh seorang penghafal al-Qur'an yang termakan hoaks bahwa sang khalifah telah melakukan KKN. Khalifah Ali bin Abi Thalib dibunuh oleh kelompok Khawarij, yang memfitnah dirinya adalah seorang penista al-Qur'an karena ingin berdamai dengan Muawiyah bin Abi Sufyan, meninggalkan hukum Allah, melakukan tahkim (arbitrase). ${ }^{31}$

\footnotetext{
28 Pranoto, "Inspirasi Alquran dan Hadis dalam Menyikapi Informasi Hoax"..., h. 38.

${ }^{29}$ Istriyani et Widiana, ., 300.

${ }^{30}$ Marzani Anwar, "Kisah Hoax Dalam Al-Qur'an", Prof. DR. Marzani Anwar's Blog, 9 juin 2017, https://marzanianwar.wordpress.com/2017/06/09/kisah-hoax-dalam-al-quran/.

${ }^{31}$ Fajrina Eka Wulandari, "Hate Speech Dalam Pandangan UU ITE Dan Fatwa MUI", Ahkam: Jurnal Hukum Islam 5, no 2 (1 novembre 2017): 246, doi:10.21274/ahkam.2017.5.2.251-271.
} 
Berkembangnya hoaks hingga saat ini dapat disebabkan oleh masyarakat itu sendiri. Masyarakat cenderung mempercayai hoaks apabila informasi yang disajikan sesuai dengan opini atau sikap yang dimiliki terkait ketidaksukaan terhadap suatu kelompok atau aturan ataupun produk tertentu. Selain itu, masyarakat juga akan mem-percayai hoaks apabila informasi yang tersaji sesuai dengan kesukaan yang berlebihan terhadap suatu kelompok atau produk tertentu. ${ }^{32}$

\section{Generasi Berkualitas untuk Indonesia Emas}

Indonesia akan menuju kebangkitan kedua selepas seratus tahun kemerdekaannya tepatnya pada tahun 2045. Indonesia pada tahun 2045 digadang-gadang akan mencapai kebangkitan karena memiliki bonus demografi yang cukup besar. Tahun 2012-2035 merupakan masa untuk menanam generasi emas Indonesia. 33

Suatu negara akan mendapat bonus demografi jika stuktur penduduk dengan jumlah usia produktif (15-64 tahun) sangatlah besar sedangkan proporsi penduduk usia muda sudah semakin kecil dan proporsi penduduk usia lanjut belum begitu besar. Kabar ini tentunya membawa angin segar, dimana pada saat itu Indonesia akan men-dapatkan keuntungan ekonomis yang disebabkan oleh penurunan rasio ketergantungan sebagai hasil proses penurunan kematian bayi dan penurunan fertilitas dalam jangka panjang. ${ }^{34}$

Periode bonus demografi di Indonesia ini dimulai tahun 2015-2035 dengan angka ketergantungan (dependency ratio berkisar antara 0,4-0,5 yang artinya setiap 100 orang usia produktif menanggung 40-50 orang usia tidak produktif. Proporsi usia anak-anak kurang dari 15 tahun akan terus berkurang dibandingkan dengan penduduk usia kerja. ${ }^{35}$ Berdasarkan data Survei Penduduk Antar Sensus jumlah ketergantungan

32 Dona Raisa Monica, "Upaya Kepolisian Dalam Penanggulangan Tindak Pidana Penyebaran Hoax", JURNAL POENALE 5, no 2 (22 mars 2018), http://jurnal.fh.unila.ac.id/ index.php/pidana/article/view/1201.

33 Regina Ade Darman, "Mempersiapkan Generasi Emas Indonesia tahun 2045 Melalui Pendidikan Berkualitas", Edik Informatika 3, no 2 (9 octobre 2017): 73-87, doi:10.22202/jei.2017. v3i2.1320.

${ }^{34}$ Nur Falikhah, "Bonus Demografi Peluang dan Tantangan bagi Indonesia", Alhadharah: Jurnal Ilmu Dakwah 16, no 32 (31 décembre 2017), doi:10.18592/alhadharah.v16i32.1992.

35 Ibid. 
tahun 2015 adalah 49,2 berarti setiap 100 penduduk usia produktif (15-64 tahun) menanggung beban sebanyak 49,2 penduduk usia non produktif (kurang dari 15 tahun dan 65 tahun ke atas). Pada kesempatan bonus demografi ini, bangsa Indonesia mempunyai kesempatan besar memacu produktivitas dan pertum-buhan ekonomi dimana pertumbuhan ekonomi diharapkan mening-katkan saving untuk kemajuan kemakmuran bangsa. Hal ini akan memberikan dampak pada peningkatan kesejahteraan yang terasa hingga berpuluh-puluh tahun kemudian.

Selama "masih ada" sebuah negara maka masih pula dibutuhkan semangat dari pemudanya. Pemuda merupakan agent of change dari sebuah peradaban. Ir. Soekarno, seorang negarawan kharismatik bahkan memberikan pernyataan "beri aku sepuluh pemuda maka akan kuguncang dunia". Betapa hebatnya peran pemuda untuk membangun sebuah negara dan menguatkannya. Pemuda adalah generasi yang memiliki semangat juang, manusia hebat dengan ide-ide cemerlangnya yang akan mengubah suatu negara menjadi negara maju.

Kecanggihan teknologi harus terus dimanfaatkan dengan maksimal. Termasuk pula dengan canggihnya serta cepatnya akses internet dan saling berbagi informasi satu dengan lainnya, tidak membuat pemudanya "lupa daratan". Pada era ini dibutuhkan peran pemuda cerdas yang akal fikirannya bekerja tidak hanya mulutnya saja. Pemuda diharapkan dapat menciptakan, memanfaatkan, menyebarkan teknologi untuk kepentingan bersama, mempersatukan negaranya, dan membangun negaranya.

\section{E. Inspirasi al-Qur'an dalam Menanggulangi Berita Hoaks}

Berita hoaks selalu merajalela dari zaman ke zaman. Sejarah telah mengungkap betapa kejinya bahaya yang ditimbulkan dari sebuah berita hoaks. Islam dengan al-Qur'an sebagai cahaya hidup telah menjelaskan bagaimana seorang muslim bersikap mengenai berita yang diterimanya. Di dalam QS. al-Hujurat ayat 6, Allah SWT berfirman, yang artinya:

"Hai orang-orang yang beriman, jika datang kepadamu orang Fasik membawa suatu berita, Maka periksalah dengan teliti agar kamu tidak menimpakan suatu musibah kepada suatu kaum tanpa mengetahui keadaannya yang menyebabkan kamu menyesal atas perbuatanmu itu." (QS. al-Hujurat:6) 
Allah sudah memerintahkan untuk meneliti setiap berita yang di dengar terlebih jika berita itu datang dari orang fasik. Pentingnya sikap teliti terhadap berita tersebut adalah untuk waspada supaya tidak memberikan keputusan atau tindakan yang salah. Orang fasik telah memiliki predikat sebagai pendusta dan banyak berbuat kekeliruan sehingga apabila mempercayai berita tanpa diteliti ia telah mengikuti orang saik tersebut dari belakang.

Konteks diturunkannya wahyu ini adalah berkaitan dengan laporan palsu yang dibuat oleh Al-Walid Ibn Uqbah Ibn Abi Mu'ith kepada Nabi Muhammad SAW. 36 Pada suatu hadis riwayat Ahmad, diriwayatkan bahwa al-Harits yang baru masuk Islam oleh karena ajakan Nabi Muhammad SAW menjanjikan kepada Nabi akan mengajak kaumnya untuk masuk Islam serta menunaikan zakat. Ia berkata kepada Nabi:

"Ya Rasulullah, aku akan pulang ke kaumku untuk mengajak mereka masuk Islam dan menunaikan zakat. Orang-orang yang mengikuti ajakanku, akan aku kumpulkan zakatnya. Apabila telah tiba waktunya, kirimlah utusan untuk mengambil zakat yang telah kukumpulkan itu."

Ketika al-Harits telah banyak mengumpulkan zakat, dan waktu yang sudah ditetapkan telah tiba, tak seorang pun utusan Nabi menemuinya. AlHarits menyangka telah terjadi sesuatu yang menye-babkan Rasulullah marah kepadanya. Maka ia pun memanggil para hartawan kaumnya dan berkata: "Sesungguhnya Rasulullah telah menetapkan waktu untuk mengutus seseorang untuk mengambil zakat yang telah ada padaku, dan beliau tidak pernah menyalahi janjinya. Akan tetapi saya tidak tahu mengapa beliau menangguhkan utusannya itu. Mungkinkan beliau marah? Mari kita berangkat menghadap Rasulullah saw."

Sementara itu, Rasulullah SAW, sesuai dengan waktu yang telah ditetapkan, mengutus al-Walid bin 'Uqbah untuk mengambil dan menerima zakat yang ada pada al-Harits. Namun ketika al-Walid berangkat, di perjalanan hatinya merasa gentar, lalu ia pulang sebelum sampai ke tempat yang dituju. Ia melaporkan (laporan palsu) kepada Rasulullah bahwa al-Harits tidak mau menyerahkan zakat kepadanya, bahkan mengancam akan membunuhnya.

\footnotetext{
${ }^{36}$ D. Shaleh et A. Dahlan, Asbabun Nuzul: Latar Belakang Historis Turunnya Ayat-Ayat AlQur'an (Bandung: CV Diponegoro, 2000), h. 512.
} 
Mendengar laporan itu, Rasulullah mengirim utusan yang lain kepada al-Harits. Di tengah perjalanan, utusan itu berpapasan dengan alHarits dan para sahabatnya yang hendak menuju ke tempat Rasulullah. Saat bertemu, al-Harits bertanya pada utusan itu: "Kepada siapa engkau diutus?" Utusan itu menjawab: "Kami diutus kepadamu." Al-Harits bertanya: "Mengapa?" Mereka pun menjawab: "Sesungguhnya Rasulullah telah mengutus al-Walid bin 'Uqbah. Namun, ia mengatakan bahwa engkau tidak mau menyerahkan zakat, bahkan bermaksud membunuhnya." AlHarits menjawab: "Demi Allah yang telah mengutus Muhammad dengan sebenar-benarnya, aku tidak melihatnya. Tidak ada yang datang kepadaku."

Ketika mereka sampai di hadapan Rasulullah, bertanyalah beliau: "Mengapa engkau menahan zakat dan akan membunuh utusanku?" AlHarits menjawab: "Demi Allah yang telah mengutus engkau dengan sebenar-benarnya, aku tidak berbuat demikian." Maka turunlah ayat alHujurat ayat 6 sebagai peringatan kepada kaum Mukminin agar tidak hanya menerima keterangan dari sebelah pihak saja.

Adapun yang disebut sebagai orang fasiq menurut al-Maraghi adalah orang yang telah keluar dari batas-batas agama. ${ }^{37}$ Selaras dengan alMaraghi, As-Shobuni mengemukakan bahwa fasiq adalah orang yang telah melanggar batasan syara'. ${ }^{38}$ Jadi, orang fasiq adalah orang yang keluar dari ketaatan kepada Allah dan berbuat maksiat. Fasiq dibagi menjadi dua, fasiq besar (akbar) dan fasiq kecil (ashgar).

Fasiq akbar (fasik besar), identik dengan kafir akbar (kafir besar), seperti yang dilakukan oleh orang-orang munafik, golongan ini dapat mengakibatkan (mengeluarkan) dirinya dari agama Islam. Kefasikan kecil, identik dengan dosa besar yang tidak mengeluarkan pelakunya dari Islam misalnya berdusta, mencuri, zina, dan lainnya. ${ }^{39}$

Menurut kaidah kebahasaan, an-naba' berarti berita penting. Jama'nya yaitu $a b n a^{\prime}$ seperti dalam kamus. Sebagian ahli bahasa mengatakan jika $n a b a^{\prime}$ tidak dikatakan khabar apabila tidak berkaitan

${ }^{37}$ Ahmad Musthafa Al-Maraghi, Tafsir Al-Maraghi, vol. Juz 26 (Kairo: Musthofa Al-Babi AlHalabi, 1946), h. 126.

38 Muhammad Ali Ash-Shobuni, Rawai'ul Bayan Tafsir Ayatul Ahkam Minal Qur'an (Damaskus: Maktabah Al-Ghozali, 1980), h. 470.

${ }^{39}$ Siti Fahimah, "Etika Komunikasi Dalam Al-Quran : Studi Tafsir Surat Al-Hujurat Ayat 1 - 8", Madinah: Jurnal Studi Islam 1, no 2 (2 décembre 2014): h. 107. 
dengan hal yang penting, dan mempunyai faedah yang besar. ${ }^{40}$ Dari sini terlihat bahwa orang muslim diperintahkan untuk memilih dan mengkonfirmasi informasi apakah itu informasi yang penting ataukah tidak.

Mengenai kalimat fatabayyanu (maka telitilah dulu olehmu) dapat diartikan dengan mencari kejelasan dan pengetahuan. Informasi yang di dapat harus dikonfirmasi kejelasannya sehingga mengerti apa yang diperintahkan. ${ }^{41}$ Kemudian az-Zuhaili menjelaskan, fatabayyanu diartikan dengan mencari kejelasan yang nyata dan mengetahui kebenaran dari perkara yang dusta. ${ }^{42}$

Sementara itu, pada kalimat "agar jangan sampai kalian menimpakan suatu bahaya pada suatu kaum atas dasar kebodohan)." Keterkaitan makna antara ketidaktahuan dengan kesalahan sangat erat, sehingga kata "jahalah" dimaknai kesalahan. Al-Qurthubi mengatakan, "bi jahalah" maksudnya ialah secara salah.

Selanjutnya "naadimiin" diartikan menyesal terhadap sesuatu dan berharap sesuatu itu tidak terulang kembali. Manusia yang menyesal, yakni mereka yang sedih berkepanjangan dan berangan-angan bahwa hal itu tidak terjadi. ${ }^{43}$ Menurur Quraish Shihab, sikap seperti inilah yang harus ditunjukkan manusia beriman ketika melakukan suatu kesalahan, yaitu segera dan berpagi-pagi untuk menjadi orang-orang yang penuh penyesalan. 44

Hamka pun mengemukakan penafsirannya mengenai ayat ini, ayat ini jelas sekali memberikan larangan yang sekeras-kerasnya lekas percaya kepada berita yang dibawa oleh seorang fasik, memburukkan seseorang atau suatu kaum. Janganlah perkara itu langsung saja diiyakan atau ditidakkan, melainkan diselidikilah terlebih dahulu dengan seksama sekali benar atau tidaknya. Jangan sampai karena terburu menjatuhkan keputusan yang buruk atas suatu perkara, sehingga orang yang diberitakan itu telah mendapat hukuman, padahal kemudian ternyata

${ }^{40}$ Ash-Shobuni., h. 471.

41 Ibid., h. 472.

42 Wahbah Az-Zuhalili, Tafsir Al-Munir Al-'Aqidah Asy-Syari'ah Wa Al-Manhaj (Damaskus: Darul Fikr, 2009), h. 555.

${ }^{43}$ Al-Maraghi, Juz 26, h. 126.

${ }^{44}$ Quraish Shihab, Tafsir Al-Misbah (Jakarta: Lentera Hati, 2009), h. 590. 
bahawa tidak ada sama sekali salahnya dalam perkara yang diberitakan orang itu. ${ }^{45}$

\section{F. Generasi "GREAT Beretika”}

Sudah dijelaskan di atas bagaimana urgensi generasi muda dalam mewujudkan Indonesia emas 2045. Di era saat ini dimana informasi bertebaran dimana saja dan akses informasi dapat dilakukan dimana saja serta mudahnya dalam berkomunikasi serta berbagi informasi mendorong generasi muda untuk menjadi generasi cerdas. Generasi "GREAT Beretika" merupakan generasi cerdas dalam menghadapi terpaan informasi agar tidak terseret arus informasi yang tidak menentu. GREAT sendiri merupakan singkatan dari Get (terima), Read (baca), Tabayyun (konfirmasi). GREAT Beretika merupakan pedoman baik sebagai penerima informasi maupun bertindak sebagai penulis atau penyebar informasi. Islam memiliki pedoman dalam berkomunikasi yang disebut etika komunikasi Islam, dimana Islam sangat menjunjung tinggi nilai kebenaran dan kebaikan. Etika komunikasi haruslah diterapkan dimana saja tak terkecuali di dalam dunia maya sekalipun.

Get, maksud dari get disini adalah menerima informasi dari sumber yang jelas dan relevan. Seperti di dalam al-Qur'an, QS. al-Hujurat ayat 6 bahwa terdapat larangan untuk langsung mempercayai berita yang dibawa orang fasik. Dalam konteks kekinian, orang fasik dapat berupa siapa saja tanpa kenal usia, status, jabatan, agama, suku maupun ras. Tujuan mereka tentulah untuk membuat kerusuhan dan keresahan di masyarakat dengan beredarnya berita tersebut. Catatan Dewan Pers menunjukkan ada sekitar 43.000 situs di Indonesia mengklaim sebagai situs berita online. Namun, situs berita online resmi hanya sekitar 300.46 Kemudian menurut kominfo terdapat 800 ribu lebih situ hoaks di Indonesia. ${ }^{47}$ Jika tidak disaring dari mana sumbernya maka dikhawatirkan membaca berita hoaks atau bahkan menyebar- luaskannya.

\footnotetext{
${ }^{45}$ Hamka, Tafsir Al-Azhar, JUZ XXVI (Jakarta: Panji Mas, 1992), h. 191.

${ }^{46}$ Hidayah, "Langkah Cerdas Generasi Milenial di Era Digital Terhadap Informasi dan Berita Hoaks".

47 PDSI KOMINFO, "Ada 800.000 Situs Penyebar Hoax Di Indonesia", Website Resmi Kementerian Komunikasi Dan Informatika RI, 12 décembre 2017. https://kominfo.go.id:443/ content/detail/12008/ada-800000-situs-penyebar-hoax-di-indonesia/0/sorotan_media.
} 
Kriteria dalam menilai sumber informasi yang terdapat di internet dapat dilihat dari Presumed credibility, perlunya kejelian dalam melihat konten pada platform apakah kompeten dan ditulis dalam bahasa yang jelas. Reputed credibility, cermati latar belakang penulis konten. Surface credibility, lihat apa berita yang ditampilkan sudah sedang untuk dipandang baik dari layout dan lainnya. Cermati pula isi informasi tersebut apakah sama dengan informasi yang dipublikasikan dalam jurnal tercetak, jika informasinya berupa jurnal. ${ }^{48}$

Kriteria penilaian informasi yang didapat dari internet diperkuat oleh pendapat dari Katerattanakul dan Siau tentang dimensi yang dilihat dalam menilai kualitas informasi dari website individual antara lain dari segi intrinsik, kontekstual, representatif dan aksesibilitas. Dari sisi intrinsik, informasi bebas dari kesalahan pengetikan, informasi bisa ditelusur, dan jika terdapat tautan yang relevan. Dari segi kontekstual, terdapat informasi mengenai siapa yang bertanggung jawab akan informasi tersebut. Representatif memuat tampilan dan pemilihan typografi sesuai serta desain yang konsisten. Aksesibilitas informasi akan lebih bernilai jika memiliki navigasi di laman web tersebut. ${ }^{49}$

Untuk mengetahui apakah suatu situs benar atau hanya situs "abalabal" kita dapat mencermatinya lewat namanya. Kemudian cek keaslian foto atau video yang menjadi keterangan dari berita. Masukkan foto melalui google image dengan menu drag-and-drop di mesin pencarian. Melalui cara ini akan ketahuan situs sumber keaslian foto tersebut. Sedangkan video amati dengan cermat, video tersebut merupakan video editing atau benar-benar video asli yang masih utuh.

Read, membaca informasi secara seksama. Dengan membaca secara teliti informasi yang disajikan maka dapat dirasakan apakah ada kejanggalan terhadap suatu informasi, apakah informasi yang disajikan sesuai fakta atau malah berkebalikannya. Membaca informasi secara seksama juga diperlukan agar tahu apakah informasi yang disajikan

${ }^{48}$ Muhammad Usman Noor, "Penilaian kualitas informasi sebagai bentuk sikap tabayyun ketika menerima informasi di sosial media dan internet". BIBLIOTIKA : Jurnal Kajian Perpustakaan dan Informasi 2, no 1 (3 juillet 2018), h. 36

${ }^{49}$ Ananda Dwi Lestari, "Menentukan Skala Prioritas Sistem Informasi Layanan OPAC Studi Kasus Di Badan Perpustakaan Umum Dan Arsip Daerah Kabupaten Tulung Agung", BIBLIOTIKA: Jurnal Kajian Perpustakaan Dan Informasi 1, no 1 (5 avril 2017): h. 85, doi:10.17977/ um008v1i12017p081. 
berupa opini atau memang benar-benar fakta. Jika berita yang disajikan bersifat fakta maka menyajikan data-data dari sumber yang relevan dan dapat masuk akal. Bila informasi bersifat opini maka harus dicerna kembali. Hal ini dikarenakan opini bersifat pemikiran seseorang yang biasanya dapat terpengaruh atau bahkan mendukung salah satu pihak dan menjelekkan pihak yang lain.

Secara mendasar sifat informasi dapat dibagi menjadi 5 jenis sifat informasi, antara lain: (1) Informasi benar atau salah, berhubungan dengan kebenaran terhadap kenyataan; (2) Informasi baru, informasi benar-benar baru bagi penerima; (3) Informasi tambahan, informasi dapat memperbaharui/memberikan perubahan terhadap informasi yang telah ada; (4) Informasi korektif, digunakan untuk melakukan koreksi terhadap informasi sebelumnya yang salah; (5) Informasi penegas, dapat mempertegas informasi yang telah ada, sehingga keyakinan terhadap informasi semakin meningkat. 50

Proses menilai informasi memanglah bukan perkara mudah dan simple. Terdapat kriteria untuk menilai suatu informasi berbobot atau tidak. Internet dan khususnya media sosial merupakan media yang paling banyak dan mudah "disusupi” berbagai macam informasi hoaks. Hanya dengan sepotong informasi yang tidak tahu kebenarannya orang dapat dengan mudah menilai dan mencaci. Tanpa kita sadari pula informasi yang ada di internet maupun media sosial dapat menjadi ladang dosa dan membuat kita menjadi orang fasik. Di dalam Islam, terkenal dengan istilah tabayyun untuk menyikapi sebuah berita.

Tabayyun. Kata "tabayyun" ditafsirkan oleh salah satu mufassir, Imam As-Syaukani yang menafsirkan tabayun dengan memeriksa dengan teliti, berhati-hati dan tidak tergesa-gesa, melihat dengan keilmuan dalam sebuah peristiwa dan informasi agar menjadi jelas dan terang. Selanjutnya M. Quraish Shihab serta Aidh al-Qarni mengartikan fatabayyanu sebagai teliti dalam menerima tiap berita atau informasi yang disebarkan oleh orang fasik. ${ }^{51}$

50 Noor, "Penilaian kualitas informasi sebagai bentuk sikap tabayyun ketika menerima informasi di sosial media dan internet"..., h. 36

51 Ibid. 
Para pengguna dunia maya memang diperbolehkan untuk bebas mengekspresikan dirinya. Kebebasan itu haruslah diimbangi dengan sikap bijaksana dalam menerima, menulis dan menyebarkan informasi. Seseorang dituntut untuk kritis terhadap apa yang telah diterimanya sebelum menyebarkan ke khalayak umum. Dari ayat al-Qur'an telah diungkapkan bagaimana pentingnya untuk terus waspada dan kritis terhadap sebuah informasi.

Majelis Ulama Indonesia (MUI) telah memberikan pedoman terkait bagaimana seseorang dalam menyikapi aneka informasi yang diterimanya. Fatwa MUI tentang Hukum dan Pedoman Bermuamalah Melalui Media Sosial tercantum dalam Fatwa MUI No. 24 Tahun 2017. Berikut ini pedoman fatwa MUI mengenai verifikasi informasi/konten, yaitu:52 Pertama, setiap orang yang memperoleh konten/informasi melalui media sosial (baik yang positif maupun negatif) tidak boleh langsung menyebarkannya sebelum diverifikasi dan dilakukan proses tabayyun serta dipastikan kemanfaatannya.

Kedua, proses tabayyun terhadap konten/informasi bisa di lakukan dengan langkah berikut: a) Dipastikan aspek sumber informasi (sanad)nya, yang meliputi kepribadian, reputasi, kelayakan dan keterpercayaannya; b) Dipastikan aspek kebenaran konten (matan)-nya, yang meliputi isi dan maksudnya; c) Dipastikan konteks tempat dan waktu serta latar belakang saat informasi tersebut disampaikan.

Ketiga, cara memastikan kebenaran informasi antara lain dengan langkah: a) Bertanya kepada sumber informasi jika diketahui; b) Permintaan klarifikasi kepada pihak-pihak yang memiliki otoritas dan kompetensi. Keempat, upaya tabayyun dilakukan secara tertutup kepada pihak yang terkait, tidak dilakukan secara terbuka di ranah publik (seperti melalui group media sosial), yang bisa menyebabkan konten/informasi yang belum jelas kebenarannya tersebut beredar luar ke publik. Kelima, Konten/informasi yang berisi pujian, sanjungan dan atau hal-hal positif tentang seseorang atau kelompok belum tentu benar, karenanya juga harus dilakukan tabayyun. ${ }^{53}$

\footnotetext{
52 Pranoto"Inspirasi Alquran dan Hadis dalam Menyikapi Informasi Hoax"..., 46.

53 Ibid.
} 
Selanjutnya, Islam sangat menjunjung tinggi akhlak dan etika. Penghuni dari dunia maya merupakan manusia. Oleh karenanya, seluruh transaksi informasi maupun relasi tidak dapat dipisahahkan dari aspek etika. Kata "etika" sangat familiar terutama pada masyarakat timur karena tiap gerak dan ruang lingkupnya selalu berhubungan erat dengan etika. Etika di masyarakat timur merupakan suatu simbol identitas bagaimana menghargai sesama manusia.

Kata "etika" berasal dari bahasa Yunani yaitu "ethos" dalam bentuk tunggalnya dan "ta etha" dalam bentuk jamaknya. Kata ethos memiliki arti tempat tinggal, padang rumput, kandang, adat istiadat, akhlak, watak, perasaan, cara berpikir. Kemudian kata etha memilki makna adat kebiasaan. Dari kata tersebut lahirlah kata moral. ${ }^{54}$

Etika dengan moral seringkali disinonimkan. Moral berasal dari bahasa latin "mores" yang artinya dat kebiasaan. Jika dalam baha Indonesia diartikan pula dengan kata "susila" ${ }^{55}$ Letak perbedaan etika dan moral adalah jika etika lebih bersifat teori, jika moral lebih menonjol ke praktis. Etika juga disebut dengan etik. Etik merupakan cerminan dari pandangan masyarakat mengenai hal yang baik dan buruk serta perilaku-perilaku yang dapat diterima atau tidak di dalam suatu masyarakat. ${ }^{56}$

Etika adalah yang harus diketahui oleh setiap manusia, dalam kehidupan bermasyarakat, namun ketika menjadi prinsip benar dan salah dari perilaku setiap manusia. ${ }^{57}$ Tiap individu diciptakan dengan perbedaannya masing-masing. Perbedaan tersebut dapat dipengaruhi dari corak kehidupannya. Untuk itu kadang-kadang perilaku individu yang satu dengan yang dianggap salah oleh individu yang lain, terkadang pula bahwa etika yang satu dianggap benar oleh individu lain, sehingga terjadi peniruan perilaku dari individu yang satu kepada individu yang lain.

${ }^{54}$ Hamzah Ya'kub, Etika Islam (Bandung: Diponegoro, 1988), h. 12.

55 Ibid., 14.

${ }^{56}$ Maya Sandra Rosita Dewi, "Islam dan Etika Bermedia (Kajian Etika Komunikasi Netizen di Media Sosial Instagram Dalam Perspektif Islam )", RESEARCH FAIR UNISRI 3, no 1 (11 janvier 2019): 141, http://ejurnal.unisri.ac.id/index.php/rsfu/article/view/2574.

${ }^{57}$ Syakur Rahman, "Etika Berkomunikasi Guru Dan Peserta Didik Menurut Ajaran Agama Islam", Jurnal Ilmiah Iqra' 3, no 1 (25 février 2018): 53, doi:10.30984/jii.v3i1.549. 
Etika menururt Jonathan Crowther,58 "Of or Relating to moral principles or questions". Sedangkan J. Coulson ${ }^{59}$ mengungkapkan etika adalah "Relating to, treating of, moral or ethics; moral, behaviour". Dari pengertian keduanya antara moral dan etika hampir tidak ada perbedaannya, akan tetapi keudukan etika lebih umum dibandingkan dengan moral. Etika sendiri dipakai khalayak umum sedangakan moral untuk individu/pribadi.

Salah satu cabang dari etika adalah etika komunikasi. Etika komunikasi merupakan ilmu yang mengatur baik buruknya tata perilaku berkomunikasi. Etika komunkasi yang baik bagi muslim, yaitu sesuai dengan apa yang terkandung di dalam al-Qur'an dan Hadis yang telah dicontohkan Rasulullah SAW. Etika atau akhlak dapat mengarahkan individu dalam berkomunikasi secara santun, baik, jujur, serta tidak merugikan orang lain. Prinsip etika dapat menjadi perisai dalam menerima ataupun menyebarkan informasi.

Seperti halnya dunia nyata, di dalam dunia maya terdapat banyak keragaman sifat dan budaya. Terdapat beberapa orang yang memilki perilaku gemar mengkritik, humor yang keterlaluan, gambar yang tidak senonoh ataupun menghasut, dan terkadang semua itu melanggar batas etika. Contoh dari perilaku tersebut antaranya menyebarkan spam iklan, provokasi antar kelompok masyarakat atau pendukung subjek tertentu, diskusi tidak sehat, tulisan yang menyinggung orang lain, bodyshamming, hate speech dan tentunya yang paling meresahkan adalah adanya pesan berantai yang mengandung hoaks.

Netiquette merupakan aturan dan tata cara penggunaan internet sebagai alat komunikasi atau pertukaran data antar-sekelompok orang dalam sistem yang termediasi internet. Ketidak-sadaran pengguna internet tentang adanya etika baik yang tertulis maupun yang tidak tertulis dalam dunia maya dapat menyeret pengguna tersebut ke dalam berbagai masalah. Dalam bersikap dan berprilaku di internet sudah tertuang di dalam netiquette (networks dan etiquette). Netiquette adalah seperangkat

58 Jonathan Crowther, Oxford Advanced Pearnes Dictionary (New York: Oxford University Press, 1995), h. 393. 570. 
aturan dan tata cara penggunaan internet sebagai alat komunikasi atau sarana pertukaran informasi berbasis internet. 60

Kenyamanan merupakan hal yang didambakan setiap orang, tak terkecuali di dalam sebuah komunitas virtual. Untuk mewujudkan kenyamanan itu, maka perlu mendapatkan perhatian dari semua pihak. Generasi emas yang digaungkan haruslah tidak hanya dibekali dengan ilmu-ilmu eksak untuk kepentingan pengetahuan saja. Untuk membangun suatu bangsa yang maju dan besar, diperlukan etika untuk membenahi masyarakatnya. Moral dan etika haruslah menjadi kebiasaan dan kehidupan berbangsa dan bernegara.

Untuk mencegah penyebaran hoaks dapat dilakukan dengan beberapa cara. Cara paling efektif meraup 57.70\% menurut survei Henri Septanto ${ }^{61}$ adalah dengan pemberian edukasi kepada masyrakat. Kedua, melalui tindakan hukum sebesar 28,90\%. Mengenai aturan terhadap ancaman dari hoaks digolongkan kedalam hukum siber atau hukum telematika, dan Hukum dunia maya. ${ }^{62}$ Aturan UU No. 11 Tahun 2008 yang telah mengalami perubahan menjadi UU No. 19 Tahun 2016 pasal 28 ayat 1 dan 2. Selain itu, peraturan penyebaran berita palsu atau hoaks juga dijabarkan dalam UU No. 1 Tahun 1946 pasal 14 dan 15. Lebih khusus, pelaku penyebar berita palsu bisa dijerat dengan pasal-pasal lain terkait yakni pasal 311 dan 378 KUHP, Pasal 27 ayat 3 UU No. 19 Tahun 2016 tentang Informasi dan Transaksi Elektronik, UU No. 40 tahun 2008 tentang Penghapusan Diskiriminasi Ras dan Etnis, serta para pelaku penyebaran berita palsu juga dapat dikenakan pasal terkait ujaran kebencian (hate speech). ${ }^{63}$

Selanjutnya yang dapat dilakukan adalah dengan mengoreksi melalui sosmed sebanyak 5,70\%. Masyarakat diharapkan dapat aktif melakukan konfirmasi terhadap sebuah informasi yang di dapatkannya.

${ }^{60}$ Fahrimal, "Netiquette: Etika Jejaring Sosial Generasi Milenial Dalam Media Sosial"..., h. 72.

${ }^{61}$ Septanto, "Inspirasi Alquran dan Hadis dalam Menyikapi Informasi Hoax"..., h.160.

${ }^{62}$ Choiroh, Lailatul Utiya. "Pemberitaan Hoax Perspektif Hukum Pidana Islam". Al-Jinayah: Jurnal Hukum Pidana Islam 3, no 2 (2017), h. 336

${ }^{63}$ Nur Aisyah Siddiq, "Penegakan Hukum Pidana Dalam Penanggulangan Berita Palsu (Hoax) Menurut Undang-Undang No.11 Tahun 2008 Yang Telah Dirubah Menjadi Undang-Undang No.19 Tahun 2016 Tentang Informasi Dan Transaksi Elektronik", LEX ET SOCIETATIS 5, no 10 (22 décembre 2017): h. 26, https://ejournal.unsrat.ac.id/index.php/lexetsocietatis/article/view/18 485 . 
Keempat, pemblokiran mempunyai efektifitas $5.30 \%$ disusul dengan flagging sebesar $1,40 \% .{ }^{64}$

Setiap orang memiliki tanggung jawab untuk membentengi diri dari hoaks. Benteng pertama adalah diri sendiri. Selain itu, pemerintah, komunitas, kepolisian dan pemuka agama juga turut serta dalam upaya pencegahan penyebaran hoaks. Diharapkan generasi GREAT Beretika ini akan menjadi "pasukan imunitas informasi". Ia akan berperan menjadi combatan hoaks untuk setiap ruang yang ditempatinya baik dalam masyarakat maupun dalam dunia maya. Menjadi combatan hoaks tidaklah mudah karena ia bertugas untuk menyampaikan sebuah informasi apakah itu mengandung hoaks, propaganda, ataupun false claim. Formulasi ini dapat digunakan untuk menangkal sebuah kesalahan dimana yang disebutkan dalam al-Hujurat ayat 6: "mencelakakan suatu kaum karena kebodohan (kecerobohan", yang akhirnya kamu menyesali perbuatanmu itu."

\section{G. Kesimpulan}

Salah satu ciri majunya peradaban adalah dengan semakin pesatnya perkembangan dunia teknologi dan semakin mudahnya mengakses informasi. Pengembangan secara positif dalam membuat manusia semakin maju dalam peradabannya. Salah satu dampak dari pengembangan teknologi informasi dan komunikasi khususnya media internet adalah hoaks. Hoaks dapat ditemukan dimana saja dalam media apa saja. Pelaku penyebaran hoaks-pun kadang tidak merasa bahwa dirinya telah menyebarkan hoaks. Indonesia pada tahun 2045 mengalami babak barunya yaitu Indonesia emas 2045. Salah satu dari keuntungannya adalah berupa bonus demografi dimana penduduk usia produktif menduduki peringkat pertama terbanyak.

Generasi muda memiliki peran sangat penting dalam pertumbuhan dan pengembangan bangsa Indonesia. Salah satu perannya adalah dengan menanggulangi penyebaran hoaks. Anjuran dalam menghadapi hoaks termuat di dalam QS. Al-Hujurat ayat 6. Berdasarkan ayat tersebut lahirlah suatu konsepsi "Generasi GREAT Beretika" untuk melawan hoaks. Get atau terima informasi dari sumber yang terpercaya. Read dengan membacanya

\footnotetext{
${ }^{64}$ Septanto, "Inspirasi Alquran dan Hadis dalam Menyikapi Informasi Hoax"..., h. 160.
} 
secara seksama dan meneliti apakah konten tersebut mengandung hoaks atau tidak. Tabayyun melalui upaya untuk mengkonfirmasi dan mencari fakta mengenai informasi tersebut apakah hoaks atau memang fakta. Etika merupakan prinsip yang harus dijunjung dalam tiap kehidupan masyrarakat teak terkecuali etika di media sosial agar dunia maya memberi kenyamanan bagi semua orang. Diharapkan generasi GREAT Beretika ini akan menjadi "pasukan imunitas informasi". Ia akan berperan menjadi combatan hoaks untuk setiap ruang yang ditempatinya baik dalam masyarakat maupun dalam dunia maya.[]

\section{Daftar Pustaka}

Al-Maraghi, Ahmad Musthafa. Tafsir Al-Maraghi. Vol. Juz 26. Kairo: Musthofa Al-Babi Al-Halabi, 1946.

Andriani, Tuti. "Sistem Pembelajaran Berbasis Teknologi Informasi Dan Komunikasi”. Sosial Budaya 12, no 1 (4 août 2016), 117-26. doi:10. 24014/sb.v12i1.1930.

Anwar, Marzani. “Kisah Hoax Dalam Al-Qur'an”, Prof. DR. Marzani Anwar's Blog, 9 juin 2017. https://marzanianwar.wordpress. com/2017/ 06/09/kisah-hoax-dalam-al-quran/.

Ash-Shobuni, Muhammad Ali. Rawai'ul Bayan Tafsir Ayatul Ahkam Minal Qur'an, Damaskus: Maktabah Al-Ghozali, 1980.

Az-Zuhalili, Wahbah. Tafsir Al-Munir Al-'Aqidah Asy-Syari'ah Wa Al-Manhaj, Damaskus: Darul Fikr, 2009.

Choiroh, Lailatul Utiya. "Pemberitaan Hoax Perspektif Hukum Pidana Islam". Al-Jinayah: Jurnal Hukum Pidana Islam 3, no 2 (2017), 325-48. doi:10.15642/aj.2017.3.2.325-348.

Coulson, J. Oxford Ensiclopedic Dictionary. New York: Oxford University Press, 1991.

Crowther, Jonathan. Oxford Advanced Pearnes Dictionary, New York: Oxford University Press, 1995.

Darman, Regina Ade. "Mempersiapkan Generasi Emas Indonesia tahun 2045 Melalui Pendidikan Berkualitas". Edik Informatika 3, no 2 (9 octobre 2017), 73-87. doi:10.22202/jei.2017.v3i2.1320. 
Dewi, Maya Sandra Rosita. "Islam dan Etika Bermedia (Kajian Etika Komunikasi Netizen di Media Sosial Instagram Dalam Perspektif Islam)". RESEARCH FAIR UNISRI 3, no 1 (11 janvier 2019). http:// ejurnal.unisri.ac.id/index.php/rsfu/article/view/2574.

Fahimah, Siti. "Etika Komunikasi Dalam Al-Quran : Studi Tafsir Surat AlHujurat Ayat 1-8". Madinah: Jurnal Studi Islam 1, no 2 (2 décembre 2014).

Fahrimal, Yuhdi. "Netiquette: Etika Jejaring Sosial Generasi Milenial Dalam Media Sosial", Jurnal Penelitian Pers Dan Komunikasi Pembangunan, 22, no 1, 13 Juni 2018.

Falikhah, Nur. "Bonus Demografi Peluang dan Tantangan bagi Indonesia”. Alhadharah: Jurnal Ilmu Dakwah, 16, no 32, 31 décembre 2017. doi:10.18592/alhadharah.v16i32.1992.

Hamka. Tafsir Al-Azhar. JUZ XXVI. Jakarta: Panji Mas, 1992.

Haryatmoko. Etika Komunikasi: Manipulasi Media, Kekerasan, dan Pornografi, Yogyakarta: Kanisius, 2007.

Hidayah, Nur. "Langkah Cerdas Generasi Milenial di Era Digital Terhadap Informasi dan Berita Hoaks". KOMPASIANA, 6 novembre 2017. https://www.kompasiana.com/janurmisuwur/5a0008845a676f0 12e5ef892/langkah-cerdas-generasi-milenial-di-era-digitalterhadap-informasi-dan-berita-hoax.

Internet World Stats. "Internet Top 20 Countries-Internet Users 2018", 2018. https://www.internetworldstats.com/top20.htm.

Istriyani, Ratna et Nur Huda Widiana. "Etika Komunikasi Islam Vs Hoax Di Dunia Maya". Jurnal Ilmu Dakwah 36, no 2, 7 septembre 2017. doi:10.21580/jid.v36.2.1774.

KOMINFO, PDSI. “Ada 800.000 Situs Penyebar Hoax Di Indonesia”. Website Resmi Kementerian Komunikasi Dan Informatika RI, 12 décembre 2017. https://kominfo.go.id:443/content/detail/120 08/ada800000-situs-penyebar-hoax-di-indonesia/0/sorotan_media.

Lestari, Ananda Dwi. "Menentukan Skala Prioritas Sistem Informasi Layanan OPAC Studi Kasus Di Badan Perpustakaan Umum Dan Arsip Daerah Kabupaten Tulung Agung". BIBLIOTIKA: Jurnal Kajian Perpustakaan Dan Informasi 1, no 1 (5 april 2017), 81-90. doi:10. 17977/um008v1i12017p081. 
Maulana, Luthfi. "Kitab Suci Dan Hoax: Pandangan Alquran Dalam Menyikapi Berita Bohong". Wawasan: Jurnal Ilmiah Agama Dan Sosial Budaya 2, no 2 (30 décembre 2017), 209-22. doi:10.15575 /jw.v2i2.1678.

Media, Kompas Cyber. "BIN: 60 Persen Konten Media Sosial adalah Informasi Hoaks". KOMPAS.com, 15 mars 2018. https://nasional. kompas.com/read/2018/03/15/06475551/bin-60-persenkonten-media-sosial-adalah-informasi-hoaks.

Monica, Dona Raisa. "Upaya Kepolisian Dalam Penanggulangan Tindak Pidana Penyebaran Hoax". JURNAL POENALE 5, no 2 (22 mart 2018). http://jurnal.fh.unila.ac.id/index.php/pidana/article/ view/1201.

Mujib, Abd. "Pesan Al-Quran dalam Menyikapi Berita Hoax: Perspektif Dakwah di Era New Media". Jurnal Komunikasi Islam 7, no 1 (8 juin 2018), 42-65. doi:10.15642/jki.2017.7.1.42-65.

Mustaffa, Normah, Dr Maizatul Haizan Mahbob, Wan Amizah Wan Mahmud, Fauziah Ahmad et Helmi Abd Rahim. "Kebergantungan Internet Dan Aktiviti Online Remaja Di Lembah Kelang". Jurnal Komunikasi: Malaysian Journal of Communication 29, no 1 (2013). http://ejournal.ukm.my/mjc/article/view/15033.

Noor, Muhammad Usman. "Penilaian kualitas informasi sebagai bentuk sikap tabayyun ketika menerima informasi di sosial media dan internet". BIBLIOTIKA : Jurnal Kajian Perpustakaan dan Informasi 2, no 1 (3 jully 2018), 33-40.

Pranoto, Stepanus Sigit. "Inspirasi Alquran dan Hadis dalam Menyikapi Informasi Hoax". AL QUDS : Jurnal Studi Alquran dan Hadis 2, no 1 (22 juin 2018), 29-50. doi:10.29240/alquds.v2i1.371.

Qomariyah, Astutik Nur. "Perilaku Penggunaan Internet Pada Kalangan Remaja Di Perkotaan". Jurnal Palimpsest 1 (1 novembre 2009). http://journal.unair.ac.id/PALIM@perilaku-penggunaan-internetpada-kalangan-remaja-di-perkotaan-article-11111-media-86category-8.html.

Rahadi, Dedi Rianto. "Perilaku Pengguna Dan Informasi Hoax Di Media Sosial." Jurnal Manajemen Dan Kewirausahaan. 5, no 1 (30 juin 2017). doi:10.26905/jmdk.v5i1.1342.

Rahman, Syakur. "Etika Berkomunikasi Guru Dan Peserta Didik Menurut Ajaran Agama Islam”. Jurnal Ilmiah Iqra' 3, no 1 (25 février 2018). doi:10.30984/jii.v3i1.549. 
Ritzer, George. Teori Sosial Posmodern. Terj. Nurhadi. Yogyakarta: Kreasi Wacana, 2010.

Saputra, Eddy. "Dampak Sosial Media Terhadap Sikap Keberagaman Remaja dan Solusinya Melalui Pendidikan Agama Islam". Sosio ekons 8, no 2 (29 octobre 2016). http://journal.lppmunindra.ac.id /index.php/sosio_ekons/article/view/922.

Sa'udi, Hasan et Ahmad Hasan Irabi. Jerat-Jerat Lisan, Solo: Pustaka Arafah, 2014.

Septanto, Henri. "Pengaruh Hoax dan Ujaran Kebencian Sebuah Cyber Crime Dengan Teknologi Sederhana di Kehidupan Sosial Masyarakat". Kalbiscientia: Jurnal Sains dan Teknologi Vol. 5, no 22 août 2018.

Shaleh, D. et A. Dahlan. Asbabun Nuzul: Latar Belakang Historis Turunnya Ayat-Ayat Al-Qur'an. Bandung: CV Diponegoro, 2000.

Shihab, Quraish. Tafsir Al-Misbah. Jakarta: Lentera Hati, 2009.

Siddiq, Nur Aisyah. "Penegakan Hukum Pidana Dalam Penanggulangan Berita Palsu (Hoax) Menurut Undang-Undang No.11 Tahun 2008 Yang Telah Dirubah Menjadi Undang-Undang No.19 Tahun 2016 Tentang Informasi Dan Transaksi Elektronik". LEX ET SOCIETATIS 5, no 10 (22 décembre 2017). https://ejournal. unsrat.ac.id/index.php /lexetsocietatis/article/view/18485.

Tim APJII. "Potret Zaman Now Pengguna dan perilaku Internet Indonesia”, april 2018, 1.

Triartanto, A. Yudo. "Kredibilitas Teks Hoax Di Media Siber". Jurnal Komunikasi 6, no 2 (2015). doi:10.31294/jkom.v6i2.2464.

Wulandari, Fajrina Eka. "Hate Speech Dalam Pandangan UU ITE Dan Fatwa MUI". Ahkam: Jurnal Hukum Islam 5, no 2 (1 novembre 2017), 251271-271. doi:10.21274/ahkam.2017.5.2.251-271.

Ya'kub, Hamzah. Etika Islam. Bandung: Diponegoro, 1988.

Yulianti, Rizkia. “Generasi Emas Produktif, Indonesia Siap di Tahun 2045”. Good News From Indonesia, 2018. https://www.goodnewsfrom indonesia.id/2017/11/21/indonesia-bisa-lahirkan-generasi-emasbukan-micin. 